\title{
Diversity of grasshopper in the piedmont of mount Elum, Buner
}

\author{
Zeeshan Khan ${ }^{1}$, Zafar Ikhtiar ${ }^{1}$, Ahmad Sadiq ${ }^{1 *}$, Wali Rahman ${ }^{1}$, Hizb ur \\ Rahman $^{1}$, Imtiaz Ali ${ }^{1}$, Sardar Azhar Mehmood ${ }^{2}$, Amir Alam² and Fawad \\ $\mathrm{Khan}^{1}$ \\ 1. Department of zoology Government degree college Daggar, Buner, Pakistan \\ 2. Department of Zoology Hazara University, Manshera, Pakistan \\ *Corresponding author's email: zoologistgc820@gmail.com \\ Citation \\ Zeeshan Khan, Zafar Ikhtiar, Ahmad Sadiq, Wali Rahman, Hizb ur Rahman, Imtiaz Ali, Sardar Azhar Mehmood, \\ Amir Alam and Fawad Khan. Diversity of grasshopper in the piedmont of mount Elum, Buner. Pure and Applied \\ Biology. Vol. 11, Issue 1, pp217-225. http://dx.doi.org/10.19045/bspab.2022.110023
}

Received: $12 / 02 / 202$

Revised: 20/05/2021

Accepted: 27/05/2021

Online First: 04/06/2021

\section{Abstract}

A study from March 2019 to August 2019 was conducted to find out the diversity of Grasshopper in the piedmont of mount Elum, Buner. Its elevation is 2,800 meters. A total of 633 specimens were collected during the study period. A 22 species of grasshopper were identified under nineteen genera of three families. Members of family Acrididae (17) under 8 subfamilies were found the most abundant. Whereas, Tettigoniidae (3) has two subfamilies and Pyrgomorphidae (2) has only one subfamily. Statistical analysis indicated percentage of different species of family Acrididae is $84.2 \%$ while Tettigoniidae is $9.8 \%$ and Pyrgomorphidae is $6 \%$. The most dominant species recorded was Diabolocatantops pinguis (11\%) whereas, Euconocephalus incertus (0.6\%), indicated the lowest range. The diversity were found through analysis of different parameters like morphometric measurement such as body length, length of wings, length of femur, length of tabia, length of tarsi, length of antennae, length of pronotum with finely divider and a common scale ruler. The data were analyzed via MS Excel version 2010.

Keywords: Buner; Diversity; Elum; Exploration; Grasshopper

\section{Introduction}

Grasshoppers are large, slender, winged insects with strong hind legs and powerful mandibles, or mouth parts, suitable for chewing and biting. They have a front pair of rigid wings called tegmina and a hind pair, often bright color, large membranous wings. Their size ranges from $1-10 \mathrm{~cm}$ in length [1]. Grasshopper belongs to order Orthoptera which is the sixth largest order of insects [2], with more than 20,000 species worldwide [3]. In general, order orthoptera is classified into two sub-order such as short horned grasshopper (Caelifera) and long horned grasshopper (Ensifera) [4]. Most of them are herbivores, but some are carnivores [5]. Most grasshoppers are polyphagous and consume vegetation from various plant sources. Some of them are omnivorous and consume animal tissue and faeces as well [6].

The distribution and abundance of grasshoppers was linked to a number of factors, including vegetation, temperature, precipitation and geographical area. Temperature and rainfall are important for plant growth [7], so grasshoppers, are also 
affected by changes in plant conditions [8]. Grasshoppers are the main pests of many crops and grasslands and occupy almost all land habitats and climates are best known for their great potential to damage crops [9]. These species may be the most notable of all insect pests and are found abundant in dry grasslands and deserts [10]. Some species of grasshopper may change color, behavior and swarms at high population densities under certain environmental conditions [11].

Grasshoppers in Pakistan were found in arid and semi-arid areas. Pakistan's geographical conditions provide ideal breeding grounds for grasshoppers, which therefore pose serious threats to both irrigated and rainy crops and pastures [12].

Grasshoppers have a typical nervous system with a large set of external sensory organs. A pair of large compound eyes is on the side of the head that give a wide field of vision and can detect movement, shape, color and distance [13].

Like other insects, grasshoppers have an open circulatory system and their body cavities are filled with haemolymph. Haemolymph functions include wound healing, heat transfer and hydrostatic pressure supply. There is no gaseous exchange involving the circulatory system [14].
Grasshoppers are the utmost economic importance as they are major plant pests that can seriously damage crop growth [15], pastures, forests [16] their nutritional values and production rates. They are also beneficence to diversity, abundance and biomass [17-19].

Grasshoppers are considered to be the best source of protein food for several bird species [20]. Grasshoppers are important component of ecosystem [21]. For seasonal growth of grasses, adults as well as fourth and fifth instars of grasshopper are important because these stages are responsible for increased foliage consumption and destruction [22].

\section{Materials and Methods Study area}

District Buner, of Khyber Pakhtunkhwa is located in the Northern part of Pakistan at geographical location of $34^{\circ}-9^{\circ}$ and $34^{\circ}-43^{\circ}$ $\mathrm{N}$ latitude and $72^{\circ}-10^{\circ}$ and $72^{\circ}-47^{\circ} \mathrm{E}$ longitude. It shares the boundaries of Swat (north), Malakand (west), Mardan (south), and Indus River and Hazara Division (east). The region is surrounded by hills from all sides and is split from Swat by Elum Mountain. The population of the district is 897319 (2017). Its total area is $1,865 \mathrm{~km}^{2}$ as shown in (Fig. 1 \& 2).

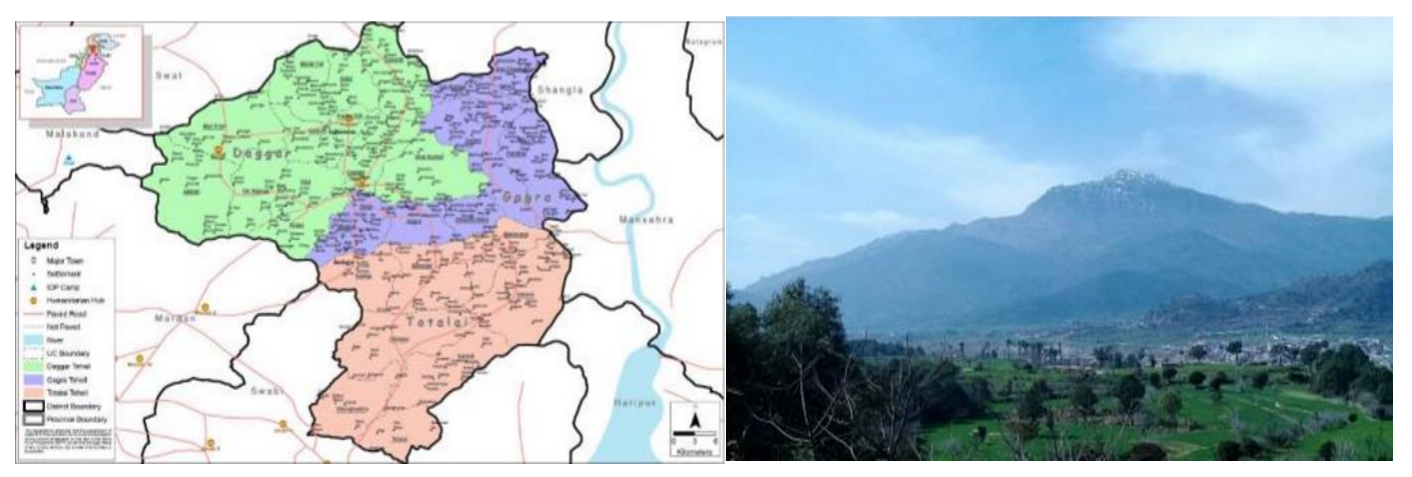

Figure 1. Map of district Buner.

Figure 2. Mountain Elum

The well-known mountain of the district is Elum. Its elevation is 2,800 meters. Its peak covered with snow in winter. It is situated at the west of Pir Baba. The recent research was conducted in the piedmont of this mountain (Elum). 


\section{Sampling}

During March 2019 to August 2019, sample collections were made. In eleven different sites of the area, specimens were collected randomly, 4 times each month between 8 am to $3 \mathrm{pm}$. A Sweep net and hand picking Method was used for the collection of Baldi and Kisbenedek [23]. The collected insects were transferred to a bottle. Soaked cotton of ethyl acetate were added to kill the specimen. The specimen was removed from the bottle after being killed to prevent color change.

\section{Storage}

In storage boxes and cabinets, pinned specimens were kept with naphthalene balls to avoid decomposition. Wet specimens were stored in plastic vials in $70 \%$ ethyl alcohol.

\section{Identification}

Specimens were relaxed for the first time. Right wings were stretched putting a piece of paper on it (if necessary) and pinned it by inserting a pin on a stretching board on the rear right thorax and were left to become dry for 72 hours. The specimens were later identified up to species level through a key designed by Sultana and Wagan [1] in Hazara University using stereoscopic microscope in accessible literature and based on external morphological characters.

\section{Morphometry and Photography}

In the measurement phase: body length, lenght of wings, femur, tabia, tarsi, antennae and pronotum were measured with finely divider and a common scale ruler. A total of 22 different species were measured. After identification and measurement, the specimens were placed on the top of a blank white sheet of paper. And then the specimens were photographed with the help of mobile camera (Galaxy J2 Prime).

\section{Results}

A total of 633 specimens of grasshopper were collected. These samples were identified and yielded into 2 sub orders such as Ensifera and Caelifera with 3 Super families Acridoidea,
Tettigonioidea and Pyrgomorphoidea. Family Acrididae is subdivided into eight subfamilies,

(Oxyinae, Oedipodinae,Acridinae, Calliptami nae,Hemiacridinae, Gomphocerinae, Eyprep ocnemidinae, and Catantopinae), 14 genera (Oxya, Gesonula, Oedaleus, Trilophidia, Dociostaurus, Acrida, Acorypha, Spathosternum, Hieroglyphus, Gonista, Heteracris, Choroedocus, Diabolocatantops, Sphodromerus) and 17 species (Oxya velox, Oxya hyla hyla, Oxya japonica, Acrida ungarica, Acrida exaltata, Gesonula punctifrons, Oedaleus senegalensis, Trilophidia annulata, Dociostaurus desius, Spathosternum prasiniferum, Hieroglyphus nigrorepletus, Gonista rotundata, Acorypha glaucopsis, Choroedocus illustris, Diabolocatantops pinguis, Sphodromerus undulates, and Heteracris pulcher). Family Tettigoniidae contains two subfamilies (Hexacentrinae and Conocephalinae), three genera (Conocephalus, Chrotogonus and Hexacentrus) and three species (Conocephalus maculatus, Chrotogonus trachypterus and Hexacentrus unicolor). Whereas, family pyrgomorphidae has only one subfamily (Pyrgomorphinae), two genera (Chrotogonus, Atractomorpha), and two species (Chrotogonus trachypterus and Atractomorpha crenulata), as shown in (Table 1).

\section{Morphometric measurement of different species}

Morphometric measurement of 22 species in (mm) for seven different parameters BL, body length; AL, antenna length; FW, forewings length; FL, femur length; TL, tabia length; tL, tarsi length; PL, pronotum length were measured and as shown in (Table 2).

\section{Month-wise abundance}

The data showed increasing trend in the abundance of species from March to August as shows in (Fig. 3). 
Table 1. Classification of collected species

\begin{tabular}{|c|c|c|c|}
\hline Order & Family & Genus & Species \\
\hline \multirow{22}{*}{ Orthoptera } & \multirow{17}{*}{ Acrididae } & Oxya & hyla hyla \\
\hline & & Oxya & japonica \\
\hline & & $O x y a$ & velox \\
\hline & & Acrida & exaltata \\
\hline & & Acrida & ungarica \\
\hline & & Gesonula & punctifrons \\
\hline & & Oedaleus & senegalensis \\
\hline & & Trilophidia & annulata \\
\hline & & Dociostaurus & desius \\
\hline & & Spathosternum & prasiniferum \\
\hline & & Hieroglyphus & nigrorepletus \\
\hline & & Gonista & rotundata \\
\hline & & Acorypha & glaucopsis \\
\hline & & Choroedocus & illustris \\
\hline & & Diabolocatantops & pinguis \\
\hline & & Sphodromerus & undulates \\
\hline & & Heteracris & pulcher \\
\hline & \multirow{3}{*}{ Tittigonidae } & Conocephalus & maculatus \\
\hline & & Hexacentrus & unicolor \\
\hline & & Euconocephalus & incertus \\
\hline & \multirow{2}{*}{ Pyrgomorphidae } & Chrotogonus & trachypterus \\
\hline & & Atractomorpha & crenulata \\
\hline
\end{tabular}

Table 2. Morphometric measurement of samples

\begin{tabular}{|c|c|c|c|c|c|c|c|}
\hline Species & BL & FWL & FL & TL & tL & AL & PL \\
\hline Acorypha glaucopsis & 52 & 46 & 25 & 23 & 7 & 12 & 10 \\
\hline Trilophidia annulata & 23 & 30 & 15 & 13 & 5 & 12 & 5 \\
\hline Hexacentrus unicolor & 28 & 40 & 25 & 25 & 7 & 42 & 5 \\
\hline Chrotogonus trachypterus & 13 & 15 & 13 & 12 & 3 & 10 & 4 \\
\hline Gonista rotundata & 32 & 28 & 15 & 13 & 3 & 6 & 5 \\
\hline Diabolocatantops pinguis & 35 & 30 & 26 & 14 & 6 & 8 & 7 \\
\hline Oxya japonica & 15 & 15 & 13 & 10 & 4 & 7 & 3 \\
\hline Oxya velox & 16 & 21 & 13 & 12 & 3 & 3 & 6 \\
\hline Spathosternum prasiniferum & 14 & 15 & 11 & 8 & 3 & 3 & 4 \\
\hline Acrida exaltata & 28 & 28 & 14 & 10 & 4 & 5 & 7 \\
\hline Oxya hyla hyla & 36 & 34 & 14 & 11 & 4 & 8 & 4 \\
\hline Conocephalus maculatus & 13 & 15 & 8 & 8 & 3 & 5 & 5 \\
\hline Sphodromerus undulates & 28 & 18 & 18 & 17 & 5 & 10 & 8 \\
\hline Hieroglyphus nigrorepletus & 32 & 10 & 17 & 14 & 7 & 15 & 7 \\
\hline Gesonula punctifrons & 31 & 25 & 15 & 13 & 5 & 7 & 6 \\
\hline Oedaleus senegalensis & 12 & 13 & 14 & 13 & 3 & 11 & 6 \\
\hline
\end{tabular}




\begin{tabular}{|c|c|c|c|c|c|c|c|}
\hline Choroedocus illustris & 38 & 25 & 24 & 24 & 6 & 7 & 5 \\
\hline Atractomorpha crenulata & 28 & 23 & 13 & 12 & 3 & 6 & 6 \\
\hline Heteracris pulcher & 44 & 34 & 36 & 34 & 9 & 16 & 8 \\
\hline Acrida ungarica & 50 & 40 & 38 & 25 & 4 & 13 & 8 \\
\hline Euconocephalus incertus & 43 & 52 & 30 & 29 & 6 & 45 & 10 \\
\hline Dociostaurus desius & 28 & 18 & 17 & 14 & 5 & 12 & 6 \\
\hline
\end{tabular}

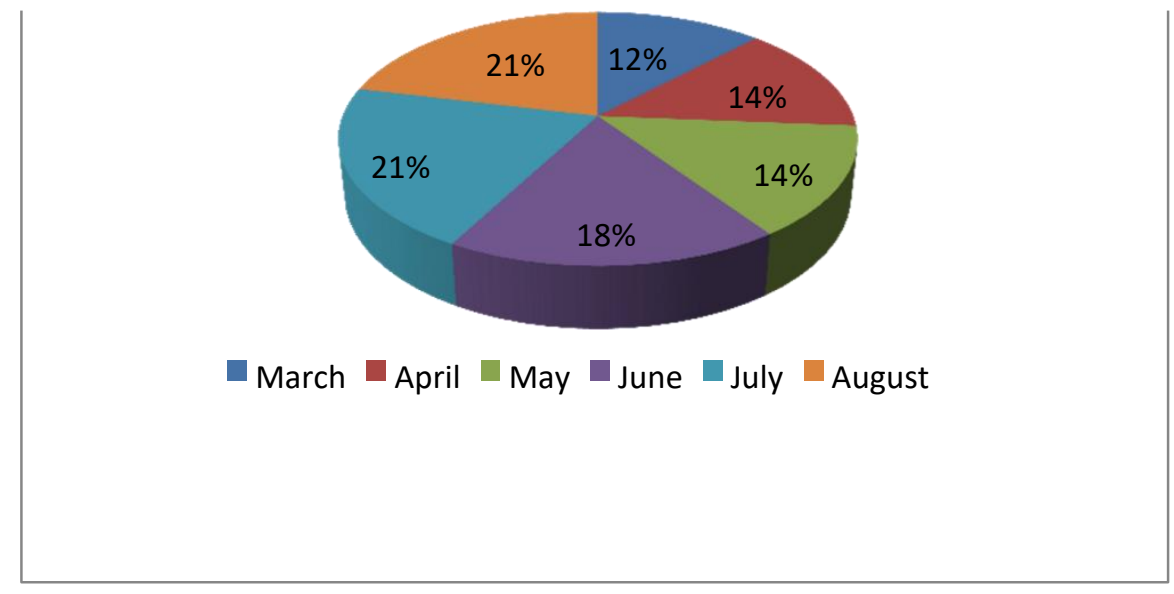

Figure 3. Month-wise abundance of grasshopper

\section{Species diversity}

Most abundant species was Diabolocatantops pinguis. Whereas, minimum value were recorded for Euconocephalus incertus. Acrididae was represented by 17 species, Tettigoniidae by 3 species and Pygrom orphoidae by 2 species. Speciesdiversityofdi Species is shown in (Fig 4).

\section{Sites of collection}

The data collected from different sites showed variations in the population size of grasshoppers. Among the 633 collected samples, the highest number of specimens were recorded from Dokada (113) followed by Ghuanday (80) Ghowandakay (70) Jowar (56) and Balokhan (54) and as in (Fig. 5).

\section{Discussion}

In the current research 2 sub order (Ensiera and Caelifera) 3 Super family (Acridoidea, Tettigonioidea and Pyrgomorphoidea), 3 families (Acrididae, Tettigonidae, Pyrgomorphidae), 11subfamilies, (Acridinae, Oxyinae, Oedipodinae, Catantopinae Hemiacridinae, Eyprepocnemidinae, Hexacentrinae, Conocephalinae, Gomphocerinae, Calliptaminae and Pyrgomorphinae), 19 genera and 22 species were recorded. The most dominant species were Diabolocatantops pinguis (11\%) whereas, Euconocephalus incertus was $0.6 \%$, indicated the lowest value of the total samplesize. 


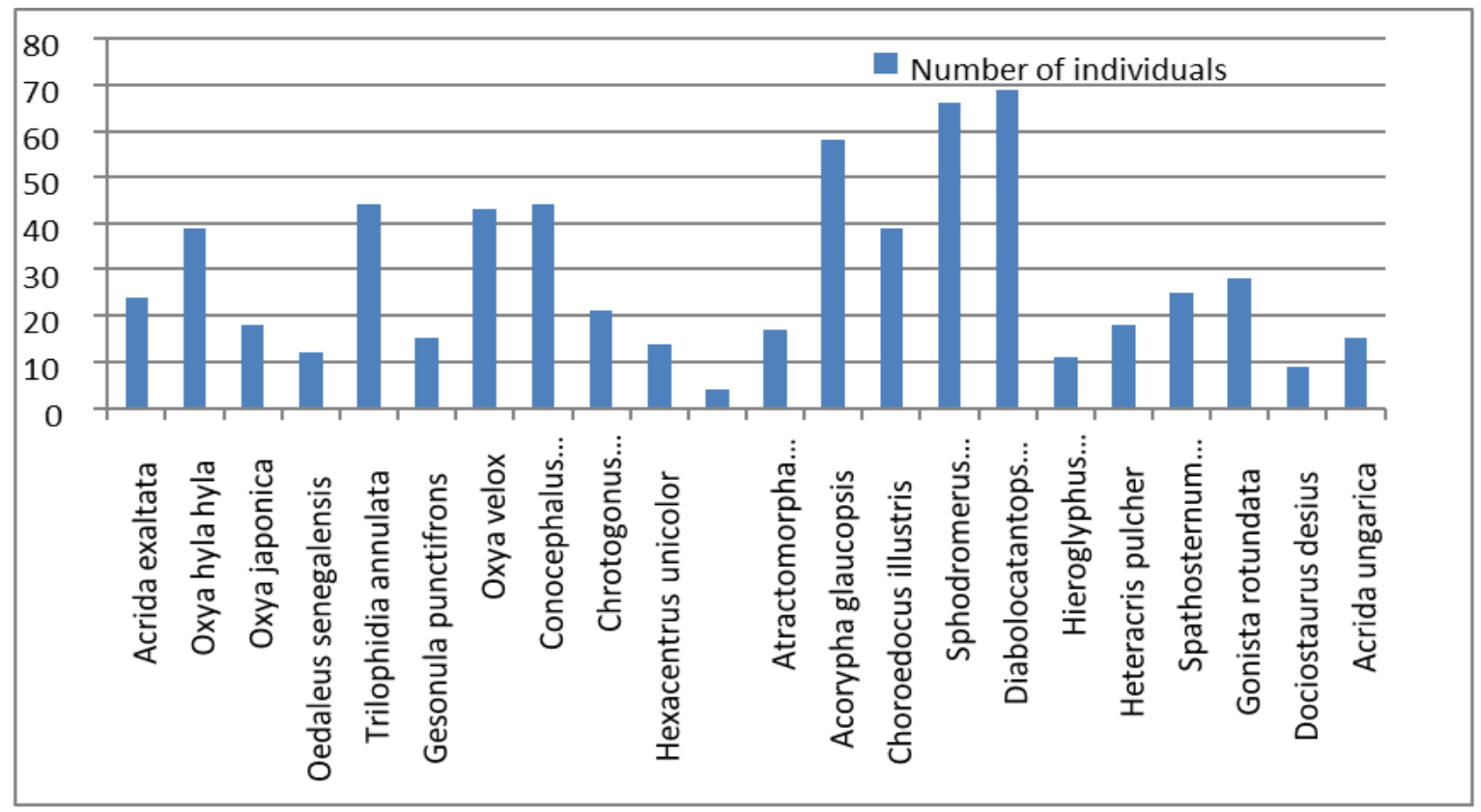

Figure 4. Species diversity of pecimens

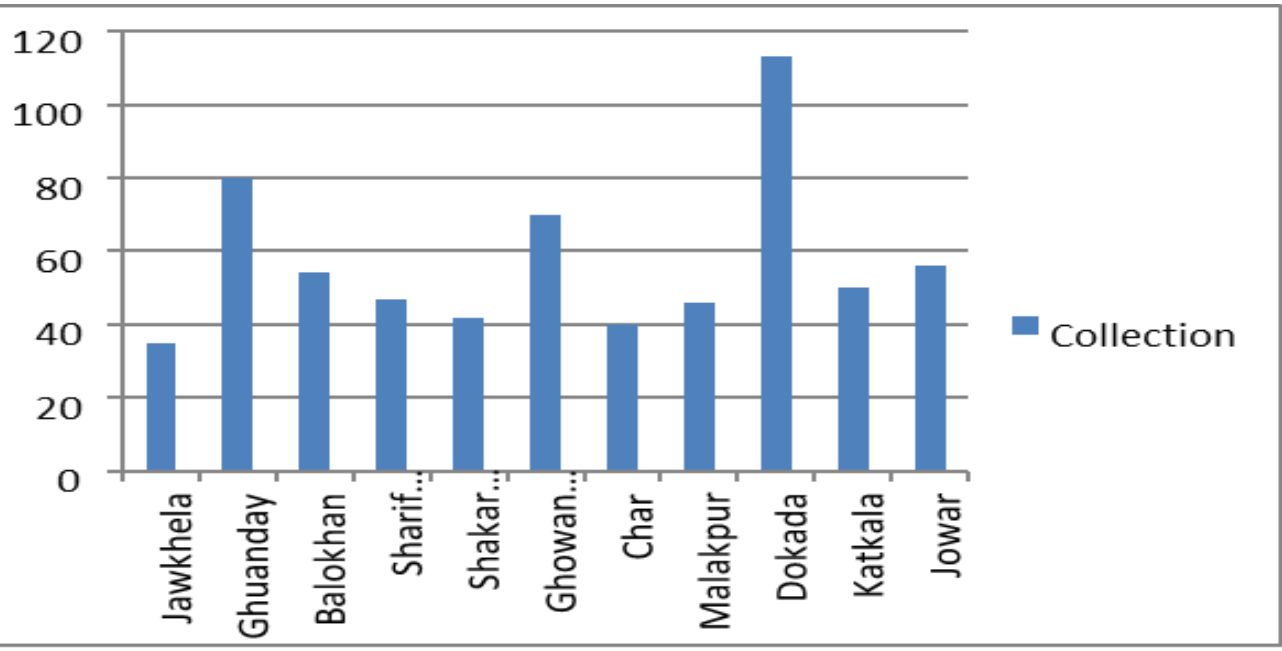

Figure 5. For collection of grasshopper from different localities

Paulraj et al. [24]. Reported 33 species under four families, similarities shows in 3 families while members of the fourth (Tetrigidae) were found absent in recent research. Acrididae family was found the most abundant in both cases indicated similarities in this regard. This similarity was also found in study reports of Capinera et al. [25], Kandibane et al. [26], and Thakur et al. [27]. Six species (A. exaltata, H. pulcher, O. hyla hyla, S. prasineferum, Tannulata and $A$. crenulata) were found similar while remaining were not reported.

Mukhtar et al. [28] reported 14 species belonged to six sub-families with twelve genera. Four subfamilies (Acridinae, Gomphocerinae, Eypreponcnemidinae and Oedipodinae) were found to be similar. Oedipodinae being a dominant subfamily with eight species whereas, in current 
research sub family Oxyinae represents four species, found to be the abundant. Common Species found in both cases were Acrida exaltata and Oedaleus senegalensis while remaining were not reported in the present work.

In Jharkhand (India), Nayeem and Usmani [29] worked on taxonomy and field observations of grasshopper and locust fauna (orthoptera: acridoidea) and collected 421 specimens under 41 species, 28 genera of 10 subfamilies, and 3 families. Subfamilies Oxyinae, Hemicridinae, Oedipodinae, Catantopinae, Eyprepocnemidinae and Acridinae were reported mutual in both cases. O. japonica, O. hyla hyla, O. velox, $H$. nigrorepletus, $S$. prasiniferum, $D$. pinguis, $A$. exaltata and T.annulata were found to be Similar, while other species were absent.

Akhtar et al. [30] observed 26 species of 14 genera belonging to 2 families, and 8 sub families. Both families (Acrididae and pyrgomorphidae) were found in the present work. Acrididae family was found to be the most abundant in both explorations which indicated similarities. All sub family was found to be similar except sub family Spathosterninae which was not found in recent study. Eleven species $(O$. senegalensis, O. japonica, O. hyla hyla, O.velox, $C$. trachypterus, A. crenulata, $G$. punctifrons. $\quad H . \quad$ nigrorepletus, $S$. prasiniferum, A. exaltata and T. annulata) were found to be similarly while other 15 species were not recorded in recent study.

Abusarhan et al. [31] collected 340 samples, under four families, ten subfamilies, and forty species. Mutually reported families are Acrididae and Pyrgomorphidae while Dericorythidae and Pamphagidae were absent. In the work of both studies estimated that family Acrididae was found to be abundant. Acridinae, Calliptaminae, Oedipodinae, Eyprepocnemidinae, Gomphocerinae and Pyrgomorphinae were found common subfamilies in both researches, while other four subfamilies were not found in recent work. Only one specie O.senegalensis were present similarly and all other species were found absent in present research.

Hussain et al. [32], stated 18 species representing 14 generas, 10 subfamilies and 3 families. All the families, (Acrididae, Tettigoniidae and Pyrgomorphidae) were reported similarly indicated agreement in research work.

Acrididae family was found the richest in both cases specified similarities in this respect. Comparable subfamilies were Acridinae, Oxyinae, Oedipodinae, Hemiacridinae, Gomphocerinae, Conocephalinae, and Pyrgomorphinae while other 3 sub families (Melanoplinae, Cyrthacanthacrinae and Phaneropterinae) were found to be absent. Hussain et al. [32], repoted $O$.hyla hyla the most abundant specie while in current research D.pinguis were found to be dominant. Six species (A. exaltata, A. ungarica, O.hyla hyla, Ojaponica, $T$. annulata and $A$ crenulata) were recorded related in both explores.

Kandibane et al. [26] sampled 21 species of grasshoppers from three families. All the three families (Acrididae, Tettigoniidae and Pyrgomorphidae) show likenesses in both researches. Five species (A.exaltata, D.pinguis, Acrenulata, Eincertus and C.maculatus) were reported to be same while other shows dissimilarity in current exploration. Oxya nititula was reported to be common and dominant specie while Diabolocatantops pinguis was the abundant specie in present study.

The distribution of several grasshopper families documented in this study were similar to that of Andersen et al. [33] who also confirmed that Acridid grasshoppers were the largest group followed by Tettigoniidae and Pyrgomorphidae in Kakadu National Park, Australia. During his study, 56 species, 46 genera were recorded, 
spread among 5 families where 3 families (Acrididae Pyrgomorphidae, and Tettigoniidae) were shows similarities but 2 families (Eumastacidae and Tetrigidae) were absent in present investigation. The fact was that there were no similar species found in both cases.

\section{Conclusion and Recommendations}

It is concluded that a total of 22 species belonging to three families, were recorded from the piedmont of mountain Elum, Pirbaba, Buner. It is the first pioneer work ever conducted. In the current research work 19 Genera has been identified and explored. The abundant family was Acrididae whereas the most abundant specie was $D$. pinguis. It is recommended to save and support the life of Grasshoppers because of its importance to diversity, abundance and biomass. It is recommended to conduct different surveys at various localities to create awareness in publics about the key role of grasshoppers in keeping blance of ecosystem. For further investigation and accuracy molecular characterization should be done to achieve the need of modern world.

\section{Authors' contributions}

Conceived and designed the experiments: $\mathrm{Z}$ Khan, Performed the experiments: Z Ikhtiar, A Sadiq \& SA Mehmood, Analyzed the data: W Rahman, $H$ Rahman \& $F$ Khan, Contributed materials/ analysis/ tools: Z Khan \& Z Ikhtiar, Wrote the paper: Z Khan \& Z Ikhtiar.

\section{References}

1. Sultana R \& Wagan MS (2015). Grasshoppers and Locusts of Pakistan. Edition 1, Higher Education Commission, Pakistan, pp. 22-34

2. Alfred JRB (2003). Diversity, Dimension and Significance of insect: An overview in Indian context, In: Nat Symp on Fron Areas of Entomoll Res. pp. 5-7.

3. IARI (2003). New Delhi, India. Bionotes 10(3): 89.

4. Arnett RH (2000). American Insects: A Handbook of the Insects of America North of
Mexico, 2nd Edition. Boca Raton: CRC Press.

5. Panhwar WA (2015). Studies on the Systematic and Ecological Status of Tettigonioidea (Ensifera) of Pakistan, Department of Zoology, University of Sindh, pp. 1-242.

6. Hoell HV, Doyen JT \& Purcell AH (1998). Introduction to insect biology and diversity, 2nd ed. 391-394. Published by Oxford Univesity Press, pp. 392-394. ISBN 0- 19510033-6.

7. Goggy D (2015). Grasshoppers ArizonaSonora Desert Museum, Archived from the original on 7 May 2015.

8. Clark EJ (1949). Studies in the ecology of British grasshoppers. Transactions of the Royal Entomol Soc of London 99: 173-222.

9. Anderson NL \& Wright JC (1952). 'Grasshopper investigations on Montana rangelands Bulletin- Montana. Agric Exper Sta 486: 1-46.

10. Emosairue SO (2007). Fundamentals of Agriculture Entomology, 1st Ed. Ethiope Publishing Corporation; Benin.

11. Gates R, Helbig B \& Beutler M (2015). Grasshopper outlook on rangelands: 2015, South Dakota State University. Publication: 02-2000-2015.

12. Forsman A, Ringblom K, Civantos E \& Ahnesjö J (2002). Coevolution of color pattern and thermoregulatory behavior in polymorphic pygmy grasshoppers Tetrix undulata, Evolution 56(2): 349-360.

13. Soomro S \& Wagan MS (2005). 'Notes on Subfamily Calliptaminae (Acrididae: Acridoidea: Orthoptera) of Pakistan, with the Description of one New Species. Pak J Zool 37(3): 229-236, 2005

14. Ruppert, Edward, Fox E, Richard, Barnes S \& Robert D (2004). Invertebrate Zoology, 7th edition, Cengage Learning. pp. 735-737.

15. Meyer \& John R (2009).'Circulatory system',General Entomology. NC State University. Archivedfrom the original on 3 January 2017.

16. Parihar DR (1987). Grasshopper Pests of GrazingLand Vegetation and Their Management In Indian Desert, Central. Ari Zon Res Inst Jodhpur India. pp. 130. 
17. Joshi PC, Lockwood JA, Vashishth N \& Singh A (1999). Grasshopper (Orthoptera: Acridoidea) community dynamics in a moist deciduous forest in India', $J$ of Orthopteran Res 1999; 8:17-23.

18. Sanjayan KP (1994). Relationship between grasshopper and crops in an agroecosystem of Tamil Nadu. India. Beiträge zur Entomol 44(1): 232-241.

19. Watts JG, Hewitt GB, Huddleston EW, Kinzer HG, Lavigne RJ \& Ueckert DN (1989). Rangeland entomology. Edison Press, Denver, Colorado. pp. 388.

20. Joern A \& Gaines SB (1990). Population dynamics and regulation in grasshoppers. In. Chapman RF \& Joern A (Eds.). Biology of grasshoppers, New York: Wiley. pp. 415482.

21. Lockwood JA (1997). Rangeland grasshopper ecology. In Gangewere, SK, Muralirangan MC \& Muralinrangan M (Eds.). Bionomics of grasshoppers (Katydids and their Kins). pp. 83-102. London: CABI.

22. Jiguet F (2002). Arthropods in diet of Little Bustards Tetrax tetrax during the breeding season in western France: Seasonal, age-and sex-related variations in the diet were studied during March to October. Bird Study 49: 105-109.

23. Baldi A \& Kisbenedek T (1997). Orthopteran assemblages as indicators of grassland naturalness in Hungary. Agric Ecosys Environ 66: 121-129.

24. Paulraj MG, Anbalagan V \& Lgnacimuthu, $S$ (2009). Distribution of Grasshop- pers (Insecta: Orthoptera) among different host plants and habitats in two districts of Tamil Nadu, India. J of Threatened Taxa 1(4): 230233.

25. Capinera JL, Scherer CW \& Simkins JB (1997). Habitat associations of grasshoppers at the Macarthur agro-ecology research center, Lake placid, Florida. Florida Enıomotogist 80(2): 253-261.
26. Kandibane M, Raguraman S, Ganapathy N \& Gunathilagaraj K (2004). Orthopteran diversity in irrigated rice ecosystem in Madurai,Tamil Nadu. Zoos Print J 19(10): 1663-1664.

27. Thakur SK, Shishadia MS, Wehta HS \& Mattu VK (2004). 'Orthopteran diversity of Roper Wetland Punjab, India. Zoos' Zoos' Print J 19(11): 1697.

28. Mukhtar G, Nawaz M, Nawaz Y \& Kakar A (2010). Biodiversity and Occurrence of Grasshoppers (Acrididae: Orthoptera) of Quetta Division Balochistan. Pak J Zool 42(1): 87-91.

29. Nayeem R \& Usmani K (2012). 'Taxonomy and field observations of grasshopper and locust fauna (Orthoptera: Acridoidea) of Jharkhand, India. Munis Entomol \& Zool 7(1): 391-417.

30. Akhtar MH, Usmani MK, Nayeem MR \& Kumar H (2012). Species Diversity and abundance of Grasshopper fauna (Orthoptera) in rice ecosystem. Annals of Biol Res 3(5): 2190-2193.

31. Abusarhan M, Zuhair S, Amr-Ghattas M, Elias N Handal \& Mazin B Qumsiyeh (2017). 'Grasshoppers and locusts (Orthoptera: Caelifera) from the Palestinian territories at the Palestine Museum of Natural History', Zool and Ecol 27(2): 143-155.

32. Hussain M, Akbar R, Malik MF, Kazam SN \& Zainab T (2017). Diversity, distribution and seasonal variations of grasshopper populations in Sialkot, Punjab, Pakistan. Pure and Appl Biol 6(4): 1372-1381.

33. Andersen AW, Lowe LW \& Rentz DCF (2001). The grasshopper (Orthoptera: Acridoidea, Eumastacoidea and Tettigonioidea) fauna of Kakadu National Park in the Australian seasonal tropics: biogeography, habitat associations and functional groups. Aus J of Zool 48(4): 431442. 